\title{
The Multicultural Self-organization of the Student's Linguistic Identity in the Context of Extended Foreign Language Training
}

\author{
Valentina Kartashova \\ Yevgeny Isaev
}

Institute of Philology, Department of Foreign Languages and Methods of their Teaching, Yelets State Bunin University Correspondence: Ye.A. Isaev, 141 Kommunarov St., apt. 24, 399770, Yelets, Russia

E-mail: evg77237009@yandex.ru

\section{Doi:10.5901/mjss.2015.v6n5s4p47}

\begin{abstract}
The article discusses the theoretical and practical aspects of the multicultural self-organization of the student's linguistic identity in the context of extended foreign language training. According to the authors' point of view the methodological basis of the dialogue of cultures is presented by the philosophy of mutual understanding, mutual relationships in the global environment today. The change of the paradigm of the socio-cultural context of foreign language training allows one to choose multicultural (learning a foreign language on a "native culture - the culture of the target language country - world cultures" principle) and activity (the development and functioning of an individual in the activity process where the starting point is the inclusion of individuals into the world of culture and their self-development) approaches as priorities. The content of extended training is oriented at the anticipatory reflection of the problems of society, industry, science, culture and other spheres of social practice and it is based on the principles of humanism and diversification. The authors present an experience of the scientific and methodical development and implementation of extended foreign language training system, providing the multicultural selforganization of the student's linguistic identity on the basis of the Department of Foreign Languages and Teaching Methods at the Yelets State Ivan Bunin University. The description of retraining program "The Multicultural Self-organization of the Specialist in Business, Management and Tourism (the English language)" intended for students of non-linguistic majors. The article has shown a positive dynamics of the foreign language proficiency, the development of the linguistic identity's global attitude to the culture and his/her cultural identity.
\end{abstract}

Keywords: extended education, foreign language, multicultural self-organization, student's linguistic identity, methodology.

\section{Introduction}

\subsection{Introduction to Problem Solving}

At present the modern society demands specialists who speak foreign languages and have the ability to accept a variety of views on philosophical questions, to promote mutual understanding and cooperation between the representatives of other nationalities, ethnic groups, races, religions and social statuses. Article 14 of the Federal Law on Education states that a person must be "integrated into the national and world cultures and aimed at improving of his/her surrounding society" (Zakon, 2011). In the federal state educational standards of higher education the formation of the ability to communicate orally and in writing in Russian and foreign languages to meet the challenges of personal and intercultural interaction is announced as a requirement to the results of the acquisition of bachelor's degree programs. All that makes actual the problem of multicultural self-organization of the student's linguistic identity.

\subsection{Importance of the Problem}

The most significant characteristic of the $20^{\text {th }}$ century is globalization. There is a convergence of nations, the emergence of a single interdependent world, in which economic, political and cultural ties between the countries are expanding. Under these conditions, the society itself is also changing. It becomes multicultural, both the true development of a number of universal, global characteristics and preservation of cultural identity of each individual ethnic group is important for it. These trends gave rise to the problem of self-organization of a multicultural linguistic identity, involving the formation of a new type of individual that can be dynamic, constantly changing, depending on the conditions of existence and co- 
operation with other people, carried out within the distinct national patterns of thinking and behavior, different cultural and linguistic worldviews, special psychological characteristics. In addition, the person must be a cultural identity, responsible for his/her own life path, and have unique, peculiar only to him/her mechanisms of introspection and analysis of visions of other cultural communities of the world order and a modus vivendi in it.

In connection with the above stated, the self-organization of multicultural linguistic identity is the process of mobilizing and structuring skills, abilities to develop the dialogue of cultures in exercising professional functions. According to the activity approach, multicultural self-organization should be regarded "as the unlimited sequence of dynamic processes of various properties (self-observation, self-identity, self-awareness, self-control, self-motivation) when under the influence of various circumstances restructuring (managed or unmanaged) of the system components, the introduction of new elements to its optimum state are required (Kostromina, 2010). From the effective point of view, multicultural self-organization of the student's linguistic identity is a quality expressed in the development of cross-cultural sphere of linguistic identity, the global view of culture, as well as his/her cultural identity (E.A. Isayev). Culture, as "a medium, rearing and feeding personality" (P. Florensky), "the means by which a man finds himself" (V.V.Vorobyov), provides a vector of multicultural self-organization.

\subsection{Literature Review}

In the psychological and pedagogical scientific discourse the essence of the self-organization of the identity is considered from the standpoint of consciously personal (M. I. Dyachenko, L. A. Kandybovich, N. M. Peisakhov et al.), activity-based (D. A. Ishkov, A. Y. Kiselev, M. A. Pakhmutova, L. V. Faleyeva et al.), integral (learner-centered) (S. S. Amirova, N. A. Zayenutdinova, O. N. Knyazkova, N.P. Popov, Yu. A. Tsagarelli et al.) and technical (V. I. Andreyev et al.) approaches identifying the mechanisms and means of the identity formation. The essence and the possibilities of the linguistic identity as the cognitive and communicative invariant, the generalized image of bearer of cultural-linguistic, communicative and activity-based values knowledge, attitudes and forms of behavior are more actively developed with due account for linguistic, socio-linguistic, psychological aspects of bilingualism teaching. O. A. Kolykhanova considers socio-cultural and philosophical aspects of bilingualism, A. S. Markosyan focuses on the acquisition of a second language as a theoretical and linguo-didactic problem, E. K. Chernichkina discusses the issues of the linguistic status and characteristics of artificial bilingualism. The problems of interaction between languages in bilingualism, cognitive aspects of bilingualism, meta linguistic processes associated with the recognition of phenomena of the second language under study (A. A. Zalevskaya) are actively explored. The list of urgent problems is still open. So, there is no attention of scholars to the problem of the potential realization of the extended foreign language training in the development of multicultural self-organization of the student's linguistic identity.

As it is known the language is the key to understanding different cultures, it opens a gate for the students' multicultural enrichment, creation and manifestation the cross-cultural tolerance in them and educating value-conscious attitude to native culture. A strong link between the personality and culture is the main mechanism of students' multicultural development in the study of languages and cultures. The personality development is taking place in the process of perception of modern multinational and multilingual world; understanding cultural phenomena in other countries, peoples and cultural communities; acquisition of ways of native culture presentation in a different environment (Semenova, 2011). In this case, it makes sense to talk about the importance of creating educational means of promoting the multicultural self-organization of the linguistic identity. In our opinion, based on our own experience and analysis of scientific and methodical literature, the extended foreign language training can be just that effective tool for developing the students' personality as much as possible to realize themselves, self-organize themselves closely to the topic, socially, professionally, personally, culturally (N. S. Gorshkova, G. I. Guzeyev, L. V. Zhuravleva, V. A. Lekakh, K. S. Makhmuryan, N. A. Morozova, A. V. Mudrik, G. V. Pankin et al.). As it is known, in foreign language education humanistic paradigm with the priority of human values, life activity and health of the individual, as well as his/her free development is realized; an educational component becomes important, namely, the education of love of country, national identity, social identity, civic-mindedness, respect for individual rights and freedoms, love for the environment, homeland, family; the cultural self-determination of the individual in contemporary socio-cultural environment in conditions adequate for self-realization, creative development and life-long education is provided (N. E. Bulankina). Besides, foreign language education is a universal "platform" for the "implementation" of culture into the content of the educational environment, where the culture implements its symbolic and communicational nature and is an element that links the moral, intellectual and spiritual life of society and the individual. 


\subsection{Hypothesis Statement and its Correspondence to Research Pattern}

As a working hypothesis of this study should be assumed the fact that the process of extended foreign language training will have an effective impact on the development of multicultural self-organization of the student's linguistic identity, if in the pedagogical process there is:

- realized the interaction of participants of this process based on the dialogue between cultures and the principles of multicultural and activity-based approach to foreign language education (cultural diversity of the thematic content of teaching materials; an active role in selecting and implementing individual educational route, subject determination, the autonomous development of the context of a multicultural reality);

- implemented the strategy of humanization and diversification of the content of the extended foreign language training, involving recognition of the uniqueness of the student's linguistic identity, his/her right to the admission to the values of the world and national cultures, self-determination and the choice of one's own path of development, as well as the right to acquire new necessary knowledge in the professional field;

- introduced block-modular technology of acquiring the necessary competencies and interactive forms of work in the educational process;

- created a system for monitoring the quality of foreign language education aimed at expanding the functions of control and shift emphasis from the subjective to the subjective-objective evaluation.

\section{Method}

\subsection{Basis and Approaches}

Let us consider the methodological aspects of the organization of the extended foreign language training for multicultural self-organization of the student's linguistic identity.

The study of scholars' works demonstrates that the dialogue of cultures should be regarded as a methodological basis for the development of capacities of the student's linguistic identity for multicultural self-organization so far as the dialogue of cultures is a philosophy of mutual understanding, the interrelation between cultures in today's global environment, recognizing, on the one hand, the indivisibility of cultures, i.e. their inevitable encounter at the boundary, cooperation, and, on the other hand, - their non-blending, uniqueness (Bakhtin, 1979, Bibler, 1990, Buber, 1993, Weber, 1998).

Due to changes in the socio-cultural context of the paradigm of foreign language education and the need for an extension of multicultural self-organization of the linguistic identity multicultural and activity-based approaches should become fundamental.

The importance of implementing multicultural approach (P. V. Sysoyev) is, first of all, in understanding the essence of the foreign language teaching content. From this point of view, linguistic multicultural education involves cultural diversity of thematic content of teaching materials in foreign languages and language courses for every type of culture (ethnic, social, religious, professional, territorial, etc.) (Sysoyev, 2013), thereby creating conditions for the development of multicultural students. Students' ideas of cultural diversity as a regulation of coexistence of cultures in modern multicultural area of native and foreign languages will be formed therewith (Gribova, 2012; Sysoyev, 2013). In addition, the basic strategy of the use of multicultural approach to the extended foreign language training - learning a foreign language on the principle of the "native culture - the culture of the target language country - world cultures", will enable the development of the multicultural self-organization of the student's linguistic identity - the inner person's ability to independently raise their professionalism and educate themselves in the spirit of tolerance, understanding and acceptance of people of other cultures, and cultural self-determination.

As multicultural self-organization is the development and functioning of a person in the process of activity, and "the starting point of any activity is the introduction of a person to the world of culture and his/her self-development" (Asmolov, 2007), we believe that it is the activity-based approach that should be the foundation of the organization of extended foreign language training, which is a means of the multicultural self-organization of the linguistic identity. It is the "activity that is a dynamic self-developing hierarchical system of relationships of the subject with the world, in the process of which the creation of the mental model, actualization, conversion and implementation of the interactions of the subject in objective reality mediated by the mental model take place" (Asmolov, 2007).

Psychologists confirm that the analysis of the system of activities, organizing the functioning of the individual in society, can reveal such multi-level system creating category, as the identity, including a linguistic one (N. A. Bernstein, A. N. Leontiev) (Bernshtein, 1960, Leontiev, 1975). 
Any attempts to understand the identity outside the context of the real process of the relationships of the subject in the world since the beginning make senseless the study of this identity essence, states A. G. Asmolov. To consider the identity outside the analysis of activity means not to take into consideration the focal to understanding any self-developing system question: "what" (N. A. Bernstein) does an identity appear as a very special reality "for"? The evolution of lifestyles, the development of the human psyche in the biogenesis, socio genesis and persona genesis lead to the appearance of the identity as a special "element" of the system, which provides orientation in the world of social relations and the transformation of lifestyles. Therefore, the logical operation of withdrawal of multicultural self- organization of the linguistic identity out of the process of the subject's relationship with the world culture, the withdrawal of the diversity of his/her activities prevents from the study of the specificity of the formation, development and functioning of the individual in society as an independent, self-organizing system.

\subsection{Principles}

We believe that the basis of the multicultural self-organization of the student's linguistic identity in the context of the methodology of the activity-based approach should be the principles of disciplinary determination and activity, for it is their implementation that will enhance the educational process according to extended programs, taking into account the nature of the phenomenon under consideration.

From a psychological point of view, the specificity of disciplinary determination lies in the fact that cultural objects do not independently affect the subject - the linguistic identity but determine the formation of the image of the world, only mutating in the activity, turning it into a product - cross-cultural sphere of the linguistic identity, and acquiring thus the systemic qualities - global view of culture and cultural self-determination.

In the methodology of the activity-based approach the thesis that the individual's behavior in society and his/her knowledge of the world have an active partisan nature is maintained. On this basis, the development of multicultural selforganization of the student's linguistic identity in the process of extended education is an active process of learning the world by an individual, which is stipulated by different kinds of values, goals, attitudes, needs, emotions, past experiences.

Considering that education must implement current requirements of society, we believe that its content should be oriented at the anticipatory reflection of the problems of society, industry, science, culture and other spheres of social practice (Sokolova, 2013). The essential basis is developed on the principle of humanism, i.e. recognition of the uniqueness of the individual, his/her right of admission to the values in the world and national cultures, self-determination and choice of his/her own path of development, and the principle of diversification. Diversification is evaluated as a "tool that allows the person to get necessary for him/her new knowledge both in the linguistic and professional spheres at any time and at any level of language education" (Sokolova, 2013).

\subsection{Analysis of Programs}

The review of proposals of educational services on the domestic market showed that the universities of the country have accumulated some experience in the implementation of programs of extended education and professional retraining in the field of foreign languages. The most popular are such programs as Translation Studies, Intercultural Communication, Methods of Teaching Foreign Languages, Foreign Languages in Business Communication, The Use of Foreign Languages in the Work of Middle-Ranking Administrative Staff, Corporate Intensive Courses (Professional Communication), Certification Exam Prep Course, Personal Assistant (PA) with Foreign Language Skills, Foreign Languages in the Management of Enterprises and Institutions and others.

The analysis of extended education programs indicates a lack of manuals aimed at the multicultural selforganization of the linguistic identity. Conventionally, all implemented programs can be divided into two groups:

1) programs for those receiving (received) education in foreign languages and wanting to expand their qualification capabilities or to determine the profile of their future professional activities;

2) programs for those receiving non-linguistic education, but who want to acquire a profession / competence relating to the acquisition of foreign languages, thereby increasing their competitiveness.

The foreign universities are also actively practicing further education. For example, especially popular among the present and future foreign language teachers are additional professional programs in Germany, England, France and Spain. The training time is typically from 1 to 4 weeks. Internships in various directions in the field of management, marketing, finance are of great demand. Students training in the areas of service and tourism can take an internship in the popular wellness and tourism countries. 
After analyzing the experience of Russian and foreign experts in teaching methodology engaged in extended foreign language training and identifying the pedagogical potential of this social institution, we develop and implement program of extended education in foreign languages for students who have or are getting basic educational services without a linguistic orientation.

\subsection{Description of the Experiment Content}

The extended foreign language training system developed on the basis of the Department of Foreign Languages and Teaching Methods at the Yelets State Ivan Bunin University has both universal and specific features, manifested in the goals, objectives, structure, forms of training and supervision, in particular the establishment of cultural and educational environment for the multicultural self-organization of the student's linguistic identity. The system is self-contained, selfsufficient, possessing such qualities as cumulativeness, dynamics and flexibility, allowing it to relatively independently evolve and develop.

The system developed and being implemented in practice is based on methodological principles as described above, and operates in two sub-systems: multi-level intensive English language courses and retraining program "The Multicultural Self-organization of the Specialist in Business, Management and Tourism (the English language)".

In the process of work, we do not focus only on the conceptual strategies, but also on the organizational peculiarities: the block-modular technology is selected as a technological basis for the learning process. The interactive teaching dominate among interactive forms (lectures, discussions, workshops, master classes, extra-mural issue-related classes, business games and others); practical classes, consultations are conducted, coordination of the student's independent work and practical training is carried out. Learning time mode is selected, taking into account the timetable of the curriculum for the basic education program, the students' group formation is performed on the basis of their language proficiency level.

\subsection{Quality Monitoring}

Much attention is paid to quality monitoring. In the system to monitor the teaching quality functions of diagnostics and self-diagnostics, planning, administration, forecasting, management, introspection and reflection are brought forward atop. We try to carry out:

- the transition from students' formal responses to the active development of meaning and sense by them; from the control of the final result of students' achievements to monitoring the dynamics of their progress; from authoritarianism to an equal partnership among teachers and students; from the teacher's control to the group and mutual control and individual self-control; from finding shortcomings to identifying strong points and their development; from sanctions for poor performance to providing additional support and assistance;

- the transition from the systemic to profession-oriented control: from the control of a single, isolated skill or ability to the control of integrative skills, competencies, cultural, social and professional skills, rules of conduct; from the control of language skills to the control of the level of communicative competence, educational and cognitive and compensatory skills;

- the transition from the formal to motivated control: the implementation of the transparency of the monitoring and control; the use of variation forms and types of controls;

- the transition from the subjective to subjective and objective evaluation: evaluation based on the correlation of student's specific progress results with the requirements of the educational standard by using scaling; the role of self-evaluation increases; the modular-rating evaluation is introduced (Makhmuryan, 2009).

\subsection{Description of the Program}

Below is a description of retraining program "The Multicultural Self-organization of the Specialist in Business, Management and Tourism (the English language)". 
Table 1. Description of Retraining Program "The Multicultural Self-organization of the Specialist in Business, Management and Tourism (the English language)"

\begin{tabular}{|c|c|}
\hline $\begin{array}{l}\text { neral characteristics of } \\
\text { program }\end{array}$ & he program is designed to get new skills and perform the related to them professional activities and job functions \\
\hline $\begin{array}{l}\text { Program goals and } \\
\text { objectives }\end{array}$ & $\begin{array}{cl}\text { Goals: } & \\
- & \text { the educational goal is the development of language skills of the multicultural self-organization of the } \\
& \text { linguistic identity; } \\
& \text { the practical purpose is training of specialists in foreign language communication in business, management } \\
\text { Objectives: } & \text { and tourism. } \\
- & \text { to improve the overall level of language skills in oral and written forms; } \\
- & \text { to develop the ability of the business intercultural communication in the context of dialogue of cultures; } \\
- & \text { to raise the global stance of the individual on the culture; } \\
- & \text { to form the cultural self-determination of students. }\end{array}$ \\
\hline $\begin{array}{l}\text { Formation of student } \\
\text { contingent }\end{array}$ & $\begin{array}{l}\text { Categories of students include students of non-linguistic areas of training at institutions of higher education for economic } \\
\text { and tourism qualifications. } \\
\text { Requirements to the level of expertise: English language proficiency at a level not lower than Pre-Intermediate. Those who } \\
\text { want to be trained under the program need to take an entry test to determine the sustainability skills of oral and written } \\
\text { aspects of speech, the ability to act as participants of a dialogue between cultures, to exercise global stance on culture } \\
\text { and level of cultural self-determination. }\end{array}$ \\
\hline $\begin{array}{l}\text { Expected le } \\
\text { outcomes }\end{array}$ & $\begin{array}{l}\text { The student who has mastered the program receives the qualification "Specialist in foreign language communication in } \\
\text { business, management and tourism" and will be able to conduct professional activities and perform employment functions } \\
\text { in the field of intercultural business interaction. } \\
\text { The students who successfully mastered the program, will have the following competences: } \\
\text { - } \quad \text { the ability to quickly adapt to the needs of a dynamic labor market and improvement of the market economy; } \\
\text { - } \quad \text { the capacity for tolerance in situations of inter-ethnic, inter-confessional and international contexts of } \\
\text { interaction; } \\
\text { - } \quad \text { the capacity for cultural self-determination and development of a global view of culture; } \\
\text { the ability to conduct business oral and written intercultural communication in business, management and } \\
\quad \text { tourism. }\end{array}$ \\
\hline \multicolumn{2}{|l|}{ The volume of the program } \\
\hline $\begin{array}{l}\text { The individual educational } \\
\text { route }\end{array}$ & $\begin{array}{l}\text { Students have the right to individual educational route for mastering the additional professional retraining program "The } \\
\text { Multicultural Self-organization of the Specialist in Business, Management and Tourism (the English language)". This route } \\
\text { involves the independent and / or intensive mastering subjects of this program. }\end{array}$ \\
\hline $\begin{array}{l}\text { A document issued after } \\
\text { the completion of training }\end{array}$ & Diploma of professional retraining as pe \\
\hline $\begin{array}{l}\text { The modules of the } \\
\text { program }\end{array}$ & $\begin{array}{l}\text { The practice of speech communication / British and American Studies / English language business communication: } \\
\text { business course / English in the field of tourism and service / Fundamentals of Economics and Management in English / } \\
\text { English-language description of Russian culture / Self-organization in culture: the interaction practice / Multilingual culture } \\
\text { in the aspect of cultural self-determination of identity }\end{array}$ \\
\hline
\end{tabular}

\section{Results and Discussion}

The results available from research confirmed the original hypothesis that the process of multicultural self-organization of the student's linguistic identity will be more effectively carried out under the above mentioned conditions. The implementation of the professional retraining program "The Multicultural Self-organization of the Specialist in Business, Management and Tourism (the English language)" confirmed its effectiveness and viability. So, the students who have mastered additional specialty showed better results for such parameters as the level of linguistic and speech competence, the development of cross-cultural sphere of the linguistic identity, as well as levels of sustainability of a global stance on the culture and cultural identity. In assessing the results relatively simple and diagnostically valid methods have been used. Thus, the pragmatic component of the multicultural self-organization of the student's linguistic identity, mastery of a foreign language, was confirmed with the help of questionnaires, observation, testing, ranking oral questioning of students. The manifestation of the culturally-oriented component of the analyzed identity, global view of culture and cultural self-determination were assessed by the method of expert evaluations. The experts were members of the department not involved in the scientific and methodological development and implementation of the program, employers and graduates of our university, studying in the areas of language training. The use of mathematical and statistical data processing proved the productivity of the system of the multicultural self-organization of the student's linguistic identity in the context of extended foreign language training.

The dynamics of multicultural self-organization of the linguistic identity is convincingly shown in Figure 1. 


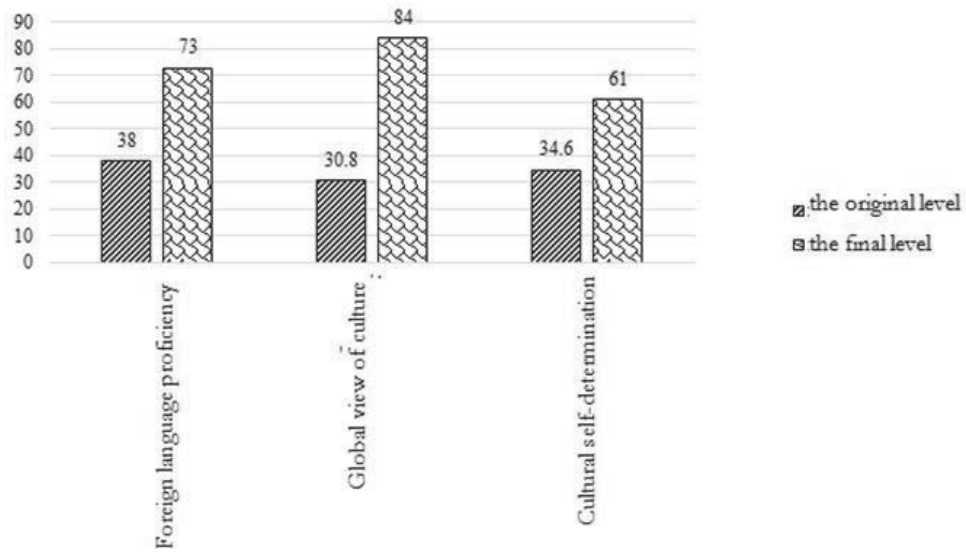

Figure 1. Dynamics of the multicultural self-organization of the student's linguistic identity

It is clear that in the context of solving the problem of the multicultural self-organization of the student's linguistic identity the similar pilot program does not exhaust the possibilities of the extended education of the prospective bachelor. Its application can also be extended to other areas. The diagnosis of the dynamics of the claimed phenomenon may be more effective.

The expansion and supplement to the methods and techniques of multicultural self-organization of the student's linguistic identity, which are based on modern information technology, may seem to be very promising.

It is obvious that the consideration of only potential of the extended foreign language education in relation to the entire educational process of training the future bachelor is insufficient. Issues of development of multicultural selforganization of the student's linguistic identity must be solved in the study of other disciplines of the basic educational program at the university. In the above context an interdisciplinary approach is quite promising. Identifying additional opportunities of the competency approach, ensuring the development of the multicultural self-organization of the student's linguistic identity at the graduate level and the preparation of highly qualified personnel is also topical.

\section{Conclusion}

Today the development of the ability of the linguistic identity to multicultural self-organization, reflecting the formation of the key values in life (democratic view, equality in relationships, healthy competition and so forth) is an important quality of a prospective employee almost in every sphere. At the same time, a didactically well-organized system of extended education is a holistic dynamic structure, which is well-positioned, including the possibility of self-development of multicultural linguistic identity of the student.

\section{References}

Asmolov, A. G. (2007). Psihologiya lichnosti: kulturno-istoricheskoye ponimaniye razvitiya cheloveka [Psychology of Personality: Cultural and Historical Understanding of Human Development]. - Moscow: Smysl: Izdatelskiy dom "Akademiya". (P. 528) [in Russian].

Bakhtin, M. M. (1979). Estetika slovesnogo tvorchestva [Aesthetics of Verbal Creativity]. - Moscow.. (P. 412) [in Russian].

Bernshtein N. A. (1960). Fiziologiya dvizheniya i aktivnosti [The Physiology of Movement and Activity]. - Moscow. (P. 450) [in Russian].

Bibler, V. S. (1990). Ot naukoucheniya - k logike kultury: Dva filosofskikh vvedeniya v dvadtsat pervyy vek [From Science to Logics of Culture: Two Philosophical Introductions to the $21^{\text {st }}$ Century]. - Moscow. (P. 413) [in Russian].

Buber, M. (1993). Ya i ty. Poslesloviye [You and Me. Afterword]. - Moscow. (P. 175) [in Russian].

Bulankina, N. E. Programma kursa povysheniya kvalifikatsii rabotnikov obrazovaniya po spetsialnosti Inostrannyie yazyki [Syllabus for Training of Educators in the Foreign Languages Qualification [electronic]. - Retrieved from: http://lib.znate.ru/docs/index213228.html [in Russian].

Gribova N.S. (2012). Metodika formirovaniya sotsiokulturnoy kompetentsii studentov napravleniya podgotovki (spetsialnosti) "Lechebnoe delo" [Methodology of Socio-cultural Competence of Students' Training (specialty) "Medicine"]: Avtoreferat dis. ... k.p.n. - Kursk [in Russian]. 
Kostromina, S. N. (2010). Strukturno-funkcionalnaya model samoorganizatsii deyatelnosti [Structural Functional Model of Self-organizing Activity]. Vestnik Sankt-Peterburgskogo Universiteta Seriya 12 Psihologiya Sociologiya Pedagogika issue 4. (pp. 151-161) [in Russian].

Leontiev, A. N. (1975). Deyatelnost. Soznanie. Lichnost [Activities. Consciousness. Personality]. - Moscow. (P. 304) [in Russian].

Makhmuryan, K. S. (2009). Teoretiko-metodicheskiye osnovy uskorennoy podgotovki uchitelya inostrannogo yazyka v usloviyah dopolnitelnogo professionalnogo obrazovaniya [Theoretical and Methodological Foundations of the Intensive Training of the Teacher of a Foreign Language in the Conditions of the Extended Vocational Training]: dis. ... d.p.n. - Moscow. (P. 421) [in Russian].

Semenova, E. V. (2011). Sovremennoye obrazovatelnoye prostranstvo $v$ kontekste izmeneniy vzaimodeystviya kultur [Modern Educational Environment in the Context of Changes in the Interaction of Cultures]. // Filosofiya Obrazovaniya. № 3(36). (pp. 148155) [in Russian].

Sokolova, E. I. (2013). Politika ES v sfere nepreryvnogo inoyazychnogo obrazovaniya [Elektronnyiy resurs] [EU Policy in the Field of Life-long Foreign Language Learning]. // Nepreryivnoe Obrazovanie: 20y Vek. Issue 2. - Retrieved from: http:trsu.ru [in Russian].

Sysoyev, P. V. (2013). Informatsionnyie i kommunikatsionnyie tekhnologii $v$ lingvisticheskom obrazovanii [Informational and Communicative Technologies in Linguistic Education]. - Moscow. (P. 264) [in Russian].

Weber, A. (1998) Izbrannoye: Krizis evropeyskoy kultury [Selectas: The Crisis of European Culture]. - Saint Petersburg: Univ. Kniga. (P. 565) [in Russian].

Zakon RF "Ob obrazovanii" [Federal Law "On Education"]. - Moscow. (P. 80) [in Russian]. 